\section{Список литературы}

1. Plessner H. Die Stufen des Organischen und der Mensch. Einleitung in die philosophische Anthropologie. - Berlin; New York, 1975.

2. Элиас H. 0 процессе цивилизации: Социогенетические и психогенетические исследования. - М.; СПб., 2001.

3. Duerr H.-P. Intimita t. Der Mythos vom Zivilisationsproze. Band 2. - Frankfurt/Main, 1990.

4. Duerr H.-P. Der erotische Leib. Der Mythos vom Zivilisationsprozeß. Band 4. - Frankfurt/Main, 1997.

5. Гергилов Р.Е. Теория цивилизации Н. Элиаса: Критика и перспективы // Вопросы культурологии. -2007. - № 5.

6. Bologne J.-C. Nacktheit und Prüderie. Eine Geschichte des Schamgefühls. - Weimar, 2001.

7. Kühn R., Raub M. M. Titze (ed.): Scham - ein menschliches Gefü hl. Kulturelle, psychologische und philosophische Perspektiven. - Opladen, 1997.

8. Petersen A. Ehre und Scham. Das Verha Itnis der Geschlechter in der Türkei. - Berlin, 1985.

9. Zuk-Nae L. Koreanische Kultur und Schamgefühl. - Frankfurt/ Main, 1998.
10. Аристотель. Риторика. Античные риторики. - М., 1978.

11. Duerr H.-P: Obszönität und Gewalt. Der Mythos vom Zivilisationsprozeß. Band 3/ — Frankfurt/Main, 1993.

12. Бенедикт Р. Хризантема и меч. Модели японской культуры. - М.: Наука, 2007.

13. Lowenfeld H. Die permissive Gesellschaft und das Über-ich. Berlin, 1976.

14. Wurmser L. Die Maske der Scham. Die Psychoanalyse von Schamaffekten und Schamkonflikten, - Berlin, 1998.

15. Schorn A. Scham und 0 ffentlichkeit. Genese und Dynamik von Scham- und Identitätskonflikten in der Kulturarbeit. Regensburg, 1996.

16. Braun A. Die Haut, die Freiheit und die zwanghafte Toleranz // Stuttgarter Zeitung, 2.3.2002, S. 49.

17. Ziehe Th., Knödler-Bunte E. (ed.): Der sexuelle Körper. Ausgeträumt? - Berlin, 1984.

18. Neckel S. Status und Scham. Zur symbolischen Reproduktion sozialer Ungleichheit. - Frankfurt; New York, 1991.

19. Lewis M. Scham. Annäherung an ein Tabu. - Hamburg, 1993.

20. Landweer H.: Scham und Macht. Phänomenologische Untersuchung zur Sozialität eines Gefühls. - Tübingen, 1999.

УДК 930.85(470+571) «19»

ББК 86.2(2)6

\title{
Д.И. САЗОНОВ
}

\section{РЕНЕГАТСТВО В ЦЕРКВИ: ПОДРЫВ УСТОЕВ ИЛИ ОЧИЩЕНИЕ? (К ВОПРОСУ ЦЕРКОВНО-ГОСУДАРСТВЕННЫХ ОТНОШЕНИЙ В КОНЦЕ 50-Х - НАЧАЛЕ 6О-Х ГОДОВ ХХ ВЕКА)}

Время «хрущевской оттепели» стало временем гонения на Русскую Православную Церковь. Одним из инструментов гонений стало явление, именуемое ренегатством, - публичный отказ от веры некоторых священников. Их «разоблачения религии» партийные органы пытались использовать для пропаганды атеистического мировоззрения. Но ренегатство не подорвало устоев Церкви. Оно лишь очистило ее ряды от приспособленцев. При наступлении новых времен в отношениях между государством и Церковью ренегатство как явление исчезло.

Ключевые слова: Церковь, ренегаты, пресса, идеология, религия, священнослужитель.

ериод конца 50-х - начала 60-х годов XX столетия, ознаменованный потеплением в политической и общественной жизни страны, для Русской Православной Церкви вошел в историю как «хрущевские гонения на религию». Всеми имеющимися средствами новая власть под руководством Н.С. Хрущева стремилась подавить в государстве инакомыслие, идеологизировать мировоззрение людей, настроить их на принятие единственно правильного учения марксизма-ленинизма, создать монолитное общество, преданное идеям коммунизма, прогресса и науки. Вековые устои православия заменялись научным атеизмом. Для выполнения поставленных задач была подготовлена юридическая и финансовая база в виде постановлений партии и правительства. Одним из агрессивных, направляющих документов подобного рода стало секретное постановление ЦК КПСС «0 записке отдела пропаганды и агитации цК КПСС по союзным республикам "0 недостатках научноатеистической пропаганды“» от 4 октября 1958 года, которое обязывало партийные, комсомольские и обще- 
ственные организации развернуть пропагандистское наступление на «религиозные пережитки» советских граждан. Государственным учреждениям предписывалось осуществлять мероприятия административного характера, направленные на ужесточение существования религиозных общин [1].

Над структурами Церкви был установлен тотальный контроль, организована откровенная антирелигиозная кампания в прессе, инициатором которой выступал идеологический отдел ЦК КПСС; практическую работу выполняли партийные функционеры и комсомол на местах. Люди подвергались дискредитации по религиозному признаку. По отношению к верующим в обществе была создана ярая атмосфера нетерпимости.

\section{Ренегатство под давлением}

В широком наступлении на религию одним из инструментов, направленных на подрыв авторитета Церкви в глазах верующих, на спасению их от «религиозного дурмана», было ренегатство ${ }^{1}$.

11 февраля 1958 года священник церкви Успения Божией Матери (что на Волковском кладбище в Ленинграде), кандидат богословия П.Ф. Дарманский направил уполномоченному Совета по делам РПЦ при Совете Министров СССР по Ленинградской области Ф.В. Федосееву заявление. В документе сообщалось, что он, Дарманский, «в связи с твердо оформившимся атеистическим мировоззрением» окончательно разрывает с религией и Православной Церковью [3, л. 12-13]. Примечательно, что еще 10 февраля 1958 года Дарманский совершал литургию. После богослужения и раздела братской кружки ${ }^{2}$, получив 4335 рублей и прихватив облачения, неожиданно уехал. На службу 12 февраля не явился [4, л. 4-5].

Что подтолкнуло Дарманского к столь кардинальной перемене, явно совершенной по чьей-то указке? Причину своего ухода из Русской Православной Церкви П.Ф. Дарманский указал вскоре в статье «Почему я порвал с религией», опубликованной 22 февраля 1958 года в газете «Киевская правда»; он объяснял свой поступок как глубоко осознанный шаг, к которому шел многие годы, так и не найдя Бога в своих религиозных поисках и научных изысканиях [5, с. 208]!

Публичный характер отречения, явная эпатажность заявления, рассчитанного на людей, нестойких в вере, свидетельствовало о том, что Дарманский явно исполнял чью-то волю, а именно - КГБ, органа, который в лице 4-го (церковного) отдела 5-го управления вел оперативно-агентурную деятельность в Церкви. Согласно рассекреченным документам того времени, П. Дарманский

\footnotetext{
${ }^{1}$ Ренегат (лат. renegatus, от renego - отрекаюсь) - лицо, перешедшее из одного вероисповедания в другое; в переносном смысле - человек, изменивший своим убеждениям и перешедший в лагерь противников, отступник, изменник [2].

2 Деньги, полученные за требоисправления.
}

действительно был агентом, внедренным в церковные структуры [6, с. 620].

Однако самым громким антирелигиозным выступлением стало отречение от Бога ученого-богослова, профессора Ленинградской Духовной Академии, протоиерея А.А. Осипова. 6 декабря 1959 года в газете «Правда» была опубликована его статья «0тказ от религии - единственно правильный путь». Осипов объяснил свой уход из Церкви «антинаучностью религиозного мировоззрения» [7, с. 4]. Спустя две недели газета «Известия» поместила большое интервью с Осиповым под общим заголовком «Разум против мистики», в котором «разуверившийся» священнослужитель на всю страну заявил, что «русское православие - самая отсталая в научно-прогрессивном отношении из всех христианских церквей мира». Вскоре в отдел пропаганды и агитации ЦК КПСС поступило два труда А.А. Осипова: аналитические обзоры «0б общем положении православия в СССР» и «0б антирелигиозной работе», подготовленные им также по заданию КГБ [8, с. 367]. И они были не последними.

Попытка дать портрет Осипова-человека, понять, что же привело его к такому финалу, предпринята в книге С.Л. Фирсова «Апостасия: “Атеист Александр 0сипов” и эпоха хрущевских гонений на Русскую Православную Церковь». Автор книги убедительно показывает и называет ряд причин, приведших Осипова к фатальному решению: предательство обусловили нравственная слабость и непомерная амбициозность, гордыня и недостаточная воцерковленность [9, с. 127]. Примечательно, что в газетной статье, декларирующей его отказ от веры, Осипов вспоминал, как он колебался, стоит ли ему принимать сан священника: его смущала, во-первых, необходимость носить рясу, «вторым “но" для меня явились <...> богослужение и молитвенное словоблудие православия» [9, с. 128]. Невзирая на внутренний протест, на колебания, он все-таки принял сан. По прямому указанию КГБ новоиспеченный атеист пошел на открытый разрыв с РПЦ [10, с. 184]. В печатных выступлениях Осипов пытался подвести идейные основы под свои действия, но его поступок, конечно же, показывал прежде всего духовно-нравственное падение. В Центральном государственном архиве Санкт-Петербурга С.Л. Фирсову удалось обнаружить документы, из которых следовало, что еще в конце сороковых годов Александр Осипов был завербован КГБ в качестве осведомителя. Сохранилась одна из его докладных записок от 1951 года на имя Александра Ивановича Кушнарева - уполномоченного Совета по делам РПЦ по Ленинградской области. В ней Осипов подробно описывает положение дел в семинарии, академии и епархии и дает несколько советов, что нужно сделать, чтобы Церковь как можно скорее утратила свое влияние в обществе [9, с. 620].

Подобные прецеденты не были единичными, скорее - знамением времени. Публичные выступления отдельных отрекшихся от Церкви людей явно носили 
заданно-показной характер. И понятно, что это была идеологическая установка партийных органов сверху донизу, осуществляемая через спецслужбы, а сами ренегаты были лишь марионетками в их руках.

Цель, которую преследовали отреченцы и их вдохновители, банальна - показать гражданам, что если такие люди, как ученые, профессора, «столичное духовенство», «церковная интеллигенция», разочаровываются в вере, не найдя Бога, признают, что научное мировоззрение выше религиозного, то людям, менее сведущим в религии, и подавно надо отказаться от «религиозного дурмана». Вероотсупники откровенно поддерживали пропагандистские постулаты ЦК КПСС: подлинны лишь идеи будущего коммунистического общества, очищенного от «пережитков капитализма в сознании и поведении людей».

Показательные выступления ренегатов в центре не преминули эхом прокатиться по стране. Так, вскоре в Рязанской епархии от духовного сана отказались трое священников: Теплоухов С., Ларин С., Садовников П.; в Тамбовской - двое: Семин К., Косых А.; в Ставропольской - трое, во Владимирской - один [11, с. 123]. «Удачная» кампания стала поводом для усиления давления властных структур на духовенство. Например, в Уфимской епархии старший налоговый инспектор А. Бодулев принуждал священника Н. Федянина закрыть приход и отречься от священства, приводя в качестве образца случаи разрывов с Церковью среди столичного духовенства [11, с. 84]. В Ульяновской области уполномоченный Совета по делам РПЦ И. Кошман вызывал к себе молодых священников, агитируя их бросить службу в церкви и суля устройство на гражданскую работу.

Гонения на Церковь к концу 60-х годов XX столетия приобрели небывалый размах. Кроме правоохранительных и партийных органов, в работу по распропагандированию духовенства активнее включились советские органы власти, руководство и коллективы предприятий, общественные организации, подключались родственники [12, с. 109]. Так, в Башкирской АССР, в селе Ипутки местные руководители, пригласив к себе священника И. Печникова, стыдили его за службу в церкви, принуждая отказаться от духовного сана [1, с. 12-13].

Всего в 1958-1964 годы на путь вероотступничества встали около двухсот священнослужителей Московской патриархии [7, с. 4]. Среди них были люди, по-разному пришедшие в Церковь, разных возрастных групп, положения, воспитания и образования. У части из них вполне успешно складывалась церковная карьера; они не испытывали материальных затруднений, не подвергались серьезным преследованиям властей. Почему же они вставали на путь сотрудничества со спецслужбами? Что же сподвигло их к разрыву с религией? Как показывает анализ подобных прецедентов, ответ кроется прежде всего в личностных качествах: малодушии и цинизме, внутренней раздвоенности и беспринципности, безнравственности и бездуховности, страхе перед властями. Все это и приводило «нестойких в вере людей» к духовной катастрофе: многие из них становились информаторами спецслужб. Таковы были плоды тотальной кампании КПСС по борьбе с религией.

\section{«Они вышли от нас, но не были наши....”}

Кроме причин, приведших к ренегатству в РПЦ обозначенных выше, следует рассмотреть и такой факт, как смена поколений священнослужителей. К 1950-1960-м годам лучшая и достойная часть православного клира после «чисток» в годы «воинствующего атеизма» (19201930-е годы) погибла. Остальная часть духовенства, рукоположенного в дореволюционные годы, уходила из жизни по естественным причинам. Сказывалась нехватка и неподготовленность духовенства; не секрет, что при необходимости архиереи вынуждены были рукополагать в священнослужители людей без специального духовного образования, воспитания и культуры.

Конечно, не все, кто порывал с Церковью, были агентами КГБ: существовали и внутренние причины, приводившие клириков к духовной катастрофе. Говоря о различиях в мировоззрении духовенства разных политических систем, протоиерей Всеволод Шпиллер заметил, что духовенство, воспитанное при советской власти, понимало Церковь иначе, чем дореволюционное: оно воспитывалось в среде нерелигиозной и даже антирелигиозной, внутренне смиряясь с секулярным тоталитаризмом [13, с. 203]. У части священства в советское время религиозные убеждения не были твердыми и последовательными. Они, повинуясь душевному порыву, пошли в Церковь, но одних потом угнетало ее изолированное положение, других - враждебное отношение государства, отсутствие общественной поддержки. Подобного рода настроения толкали неустойчивых в вере людей на радикальные решения.

Среди покинувших православный клир были и такие, кто стал священнослужителем не по призванию, а в силу случайных обстоятельств. Бывший священник Николай Спасский, публично отрекшийся от веры и Церкви, заявил, что после окончания духовной семинарии сана не принял и в течение многих лет находился на гражданской службе. А в годы войны, будучи на оккупированной территории, не имея глубокой веры, по сути, вынужденно, стал православным священнослужителем [14, с. 123]. Спустя годы маловерие привело таких служителей к отречению от Бога. Характерно, что во всех публикациях ренегатов использовались одни и те же доводы: морально-бытовое разложение духовенства, триумфальные достижения науки и техники, успехи коммунистического строительства в СССР. Вот как свидетельствовал о своем отречении ренегат Е.К. Дулуман: «В свое молодое время мне была внушена вера в Бога <...> Бог не выдержал ни моих научных изучений, ни практической проверки. Теоретически и практически испытав религию и Бога, я узнал о религии и о Боге всю правду» [15].

\footnotetext{
${ }^{3} 1$ Ин., 2: 19.
} 
Немаловажными факторами, приводившими к ренегатству в 1950-1960-е годы, были и обстоятельства частной жизни духовенства. К примеру, наличие компромата в виде нахождения на оккупированной территории во время войны, родственных связей с «врагами народа», темных сторон в жизни священника - все возможное и невозможное становилось весомым аргументом для вербовки спецслужбами намеченного кандитата и давления на него с целью дискредитации того дела, которому он служил.

\section{Средства и методы борьбы с РПц}

Религиоведческие и исторические исследования конца 50-х - начала 60-х годов прошлого столетия показывают, насколько большой вред был нанесен Русской Православной Церкви и верующим хрущевской атеистической кампанией.

Идеологи «новой светской религии» - научного коммунизма, подхватив аргументы вероотступников, утверждали, что новое поколение советских людей в условиях коммунистического общества будет безбожным, что наука окончательно восторжествует над «религиозным мракобесием». Таким образом, именно ренегатство стало одним из мощных рычагов разнузданной пропагандистской кампании против Церкви и верующих, что привело к массовому закрытию монастырей и храмов, семинарий. За время гонения почти в два раза уменьшилось число храмов (в 1957 году Церковь имела 13478 храмов, к 1966 году их осталось всего 7523) и в три раза - монастырей. Установка на окончательное осуществление антицерковной программы была жесткой.

В ход было пущено все. Тюрьмы, психиатрические больницы, психотропные препараты, надругательства над паломниками, разбои и нападения на церкви и священников при полном попустительстве властей, а иногда и с привлечением военных.

Все силы идеологов были брошены на «перевоспитание» верующих и священнослужителей. Повсеместно под эгидой общества «3нание» проводились антирелигиозные лекции и выступления; режиссеры, писатели, журналисты получали так называемые социальные заказы на создание произведений, постановку фильмов, спектаклей атеистического содержания. Средства массовой информации пестрели «разоблачениями»и агитками против верующих. И очевидно, что авторы этих публикаций и сочинений радели не о научности и доказательстве истинности атеизма, а стремились эмоционально влиять на священство и верующих, создавать атмосферу нетерпимости, враждебного и уничижительного отношения к ним. Не приходится говорить и о научных изысканиях и доказательствах отсутствия Бога самих ренегатов, их научные труды были крайне посредственны, а приводимые аргументы - не выдерживали никакой критики. Это был уровень агиток: «летал в космос - бога не видел».
Известный писатель А. Левитин-Шавров описал шаблон, по которому отрабатывали свои тридцать сребреников ренегаты: «Сначала самыми черным красками рисуется духовная среда, причем выясняется, что автор очередной “исповеди" был единственным исключением из правила: был искренне верующим, бескорыстным, морально чистым человеком. Затем следует рассказ о “противоречиях" в Евангелии - вроде того, что неизвестно, в каком году умер Христос, - на что ответ уже давным-давно был дан. Однако, наш “праведник” только сейчас это заметил и "прозрел". Кончается исповедь, как правило, гимном советскому обществу, списанным из первомайской стенгазеты» [10, с. 88].

Гораздо опаснее из ренегатов были те, кто «не раскрылся», но продолжал двурушничать, те, кто продолжал свою агентурную деятельность. Они информировали уполномоченных соответствующих органов «о положении и деятельности Церкви», следили и доносили, нанося своей деятельностью реальный вред. Так, на приеме у уполномоченного по делам РПЦ по Костромской области в первом полугодии 1958 года было 26 священников, из них, 10 с информацией о положении и деятельности церкви в епархии [16, л. 19].

Гонители, конечно, не рассчитывали на сопротивление, более того, они боялись его, не имея должных аргументов к отпору. И Церковь не молчала. В ответ на отречение от веры группы священнослужителей 30 декабря 1959 года на заседании Священного Синода под председательством Патриарха Алексия было принято постановление: «Бывшего протоиерея и бывшего профессора Ленинградской Духовной Академии Александра Осипова, бывшего священника Николая Спасского, бывшего священника Павла Дарманского и прочих священнослужителей, публично похуливших Имя Божие, считать извергнутыми из священного сана и лишенными всякого церковного общения...» $[17$, с. 20]. Святейший Патриарх Московский и всея Руси Алексий обращался также к первому секретарю ЦК КПСС Н.С. Хрущеву с прошением рассмотреть вопрос о грубом административном давлении на священство $[18$, л. 1]. Широкую огласку получили протесты верующих.

Ренегатам давался достойный отпор и на местах. Коллеги по Ленинградской Духовной Академии в своем «0твете» на выступление А.А. Осипова в газете «Правда» аргументированно доказывали всю лживость доводов ренегата. Отмечая, что вера никогда не обманывала людей, авторы статьи обращали особое внимание на тот аспект, что «действительно же обманывают такие лжеучители, как сам Осипов, который, не веруя сам, за деньги учил вероучению других» [9, с. 127].

В своей апологии предателю П. Дарманскому священник С. Желудков убедительно показал, что Дарманский никогда, по сути, и не был православным. Он доказал, что чудовищная смесь диких суеверий, нелепых представлений об окружающем мире, которую Дарманский пытался выдать за христианство, на самом деле никакого отношения к этому вероучению не имеет. Рассматри- 
вая нравственный облик обличителя церковных нравов, клирик писал: «Вот он уже окончательно решил, что он - атеист; он испытывает, как он сам пишет, не просто разочарование, а прямо-таки ненависть к религии и... продолжает служить священником, воистину народ обманывает, не в силах оторваться от церковного пирога» $[10$, с. 184$]$.

Священники в проповедях без боязни зачитывали статьи ренегатов перед верующими и полемизировали с ними. Так, в разгар гонений 1959 года, секретарь Епархиального управления Костромской епархии Порфирий Груздев в проповеди перед прихожанами разбирал сочинение отреченца Н. Спасского «Почему я порвал с религией», публично отметив невысокий моральный уровень человека, отказавшегося от веры [16, л. 19].

Примечательно, что за свое выступление он не был наказан. Видимо, партийные органы хорошо знали «цену» ренегатству - первое, а второе - если им противостояли, они отступали. Это тоже была цена проводимой в стране политике.

Церковное священноначалие критически подошло и к своей деятельности, пересмотрев работу с кадрами, оно усилило контроль за служителями Церкви, благодаря чему повысился моральный, культурный, идейный уровень духовенства [6, с. 620].

По-разному сложились и судьбы ренегатов. Наиболее ловкие и предприимчивые благополучно интегрировались в советскую действительность и много лет усердно трудились на атеистическом поприще.

Тот же А.А. Осипов, объехав в период с 1960 по 1967 годы сорок два региона, прочитал не менее тысячи лекций, более трехсот раз выступал по радио и телевидению, издал тридцать книг и брошюр, написал около трехсот статей и очерков, более двухсот рецензий, провел более шестисот консультаций [19].

Однако судьба большинства клириков-ренегатов сложилась трагически. Внутренне осознав пагубность своего поступка и всю низость духовного падения, слабовольные вероотступники быстро опустились на социальное дно и потерялись в жизни. Архивные документы свидетельствуют, что многие из отрекшихся от духовного сана уже к середине 1960-х годов или спились, или покончили с собой, некоторые же раскаялись и просили принять их обратно [8, с. 367].

\section{Подрыв устоев православия или очищение?}

Благодаря уходу отрекшихся от веры людей и решимости священничества в отстаивании своих принципов, Церковь лишь очистилась от поверхностно верующих ее служителей и прихожан.

Вероотступничество как явление не было чем-то новым в жизни Церкви. С самого своего зарождения христианство знает примеры отречения и предательства.

Анализируя феномен ренегатства и обратившись к истокам христианства, в Первом соборном послании апостола Иоанна Богослова находим: «0ни вышли от нас, но не были наши: ибо если бы они были наши, то остались бы с нами; но они вышли, и через то открылось, что не все наши» (1 Ин., 2: 19).

Вспомним также евангельское отречение апостола Петра (Мф., 26:69-75) и других христиан, кто на протяжении существования Церкви покидал ее. История свидетельствует о подобных отпадениях даже в годы, которые принято называть возрождением Церкви, например только в 1947 году от сана отказался 21 человек [20, л. 4], но на тот период рычаг ренегатства в управлении страной еще не использовался.

Конечно, уход из клира и антирелигиозные выступления отдельных православных священнослужителей в 1958-1964 годах были одним из печальных прецедентов в истории страны и Церкви, возникших по заказу атеистического государства, но это было двести предателей среди миллионов верующих. Двести тех, кто дрогнул, кто испугался, кто лишь формально принадлежал к Церкви, полтора процента от тогдашней численности духовенства 4 . Плоды их деятельности ничтожны. Мало кого из подлинно верующих людей соблазнили душевные откровения ренегатов. Они настолько скомпрометировали себя в глазах верующих людей и общественности, что многие из них были убеждены, - изменники служили Церкви за деньги и были завербованы для развала Церкви спецслужбами.

Лишенные зарегистрированных церквей верующие создавали подпольные общины, неконтролируемые властями.

Таким образом, ренегатство конца 1950-х - начала 1960-х годов не оправдало ожиданий властей, считавших, что публичный отказ от религии священников станет решающим аргументом в борьбе с религиозным мировоззрением в обществе и что подвиг «героев» увлечет за собой массы. Оно не принесло тех результатов, на которые рассчитывали партийные и государственные органы. Религиозность населения в целом тоже не уменьшилась, а в ряде регионов, судя по приводимой историками статистике крещений, венчаний и отпеваний, посещения праздничных богослужений даже возросла [21, с. 356, 391].

Верующий народ с решимостью ответил на атеистическую пропаганду защитой своих святынь и веры. По имеющимся на сегодняшний день данным, только за 1961-1964 годы по религиозным мотивам было осуждено 1234 человека. Многих из них отправили в лагеря, ссылки, на поселения [21, с. 382] Случаи противодействия мерам властей в борьбе с религиозными убеждениями стали известны во всем мире, что послужило подрывом авторитета социалистического государства, недоверием к его официальной позиции по отношению к Церкви.

${ }^{4}$ В 1957 году в РПЦ насчитывалось 12288 священнослужителей [21, C. 356$]$. 
«0ттепель» для Русской Православной Церкви началась со снятия Н. С. Хрущева со всех государственных постов. Это событие послужило началом и для изменения церковно-государственных отношений в целом.

Хрущевская антирелигиозная кампания показала, что уничтожить религию крайне сложно, а может быть и невозможно. Власти пришли к неутешительным для себя выводам: гражданская и политическая лояльность граждан была подорвана, репрессивные действия властей привели не к монолитности, а к расколу в обществе. В Церковь активно возвращалась городская интеллигенция, разочаровавшаяся в «достижениях науки и прогресса», все нагляднее проявлялось недовольство давлением партийной идеологии, ущемлением свободы совести.

Правящие органы изменили тактику и по отношению к «скрытым» доносителям, убедившись, что они наносят вред не столько Церкви, сколько авторитету правящей партии, ее идеологии. Оставаясь некоторый период на прежних позициях борьбы с религией, власть существенно пересмотрела свои методы работы, поставив задачу воспитать новое поколение священнослужителей, которые сами смогли бы скомпрометировать религию в глазах верующих [22, с. 73].

В 1991 году Церковь и государство перешли на уровень отношений невмешательства в дела друг друга. И такой пропагандистский прием как ренегатство отпал, опытным путем доказав свою полную несостоятельность. Еще раз подтвердились слова Пастыреначальника Господа Иисуса Христа, сказанные о том, что «врата ада не одолеют Церковь, основанную на камне веры» (Мф., 16:18).

\section{Список литературы}

1. Усилить научно-атеистическую пропаганду // Коммунист. - 1958. — № 17.

2. Ренегат // Википедия: свободная энциклопедия [Электронный ресурс]. - Режим доступа: http://ru.wikipedia.org/ wiki/\%DO\%E5\%ED\%E5\%E3\%E0\%F2
3. Российский государственный архив Новейшей истории. Ф.5. 0п. 34. Д. 57. Л. 12-13.

4. Государственный архив Российской Федерации. Ф. 6991. 0п. 2. Д. 228. Л. 4-5.

5. Почему мы порвали с религией: сб. / сост. В. И. Голубович. - М.: Госполитиздат, 1959.

6. Цыпин B., прот. История Русской Церкви, 1917-1977. M., 1997.

7. Осипов А.А. Отказ от религии - единственно правильный путь: письмо в редакцию // Правда. -1959. - 6 дек.

8. Шкаровский М.В. Русская Православная Церковь в XX в. М., 2010.

9. Фирсов С.Л. Апостасия: «Атеист Александр Осипов» и эпоха гонений на Русскую Православную Церковь. - М.: Держава; Сатись, 2004. - (Русская церковь в XX столетии: документы, воспоминания, свидетельства).

10. Желудков С., свящ. Почему и я - христианин. - СПб., 1996.

11. Шкуратов С.А. Взаимоотношения советского государства и Русской Православной Церкви в 40-60-е годы XX в.: дис. ... канд. ист. наук. - М., 2005.

12. Государственный архив Новейшей истории Ставропольского края. Ф. 1. Оп. 2. Д. 829. Л. 109.

13. Поспеловский Д.В. Русская Православная Церковь в ХХ в. М.: Республика, 1995.

14. Гераськин Ю.В. Русская православная церковь, верующие власть (конец 30-х - 70-е гг. XX в.). - Рязань, 2007.

15. Дулуман Е.К. Как мне внушить, что Бога нет? // Атеистический сайт [Электронный ресурс]. - Режим доступа: http:// ateism.ru/duluman/nogot03.htm

16. Государственный архив Костромской области. Ф. р-2102. Оп. 5. Д. 32. Л. 19.

17. Русская Православная Церковь в советское время: в 2 кн. / сост. Г. Штриккер. - М.: Пропилеи, 1995. - Кн. 2.

18. Рукописный отдел Российской национальной библиотеки. Ф. 1152. 0п. 1. Д. 32. Л. 1.

19. Федоров С. Атеист и ваш друг Александр Осипов: как известный богослов стал яростным безбожником // Независимая газета. - 1999. - 3 нояб.

20. Российский государственный архив социально-политической истории. Ф.17. 0п. 132. Д. 7. Л.4.

21. Шкаровский М.В. Русская Православная Церковь при Сталине и Хрущеве. - М., 1999.

22. Русская Православная Церковь в советское время: в 2 кн. / сост. Г. Штриккер.- М.: Пропилеи, 1995. - Кн. 1. 